\title{
With Deft Knife and Paste: The Extra- Illustrated Books of John M. Wing
}

There is one member of the Fraternity of Book Collectors who has of late years rather fallen in the estimation of his brother Bibliophiles. This knight of the shears and paste jar... is known in bookman's parlance as the Grangerite. The title never has been understood to indicate exalted bibliophilic rank, and now, alas! the individual who bears it appears to be upon the point of losing all honorary distinction whatever in the little world of the book collector.

-W. L. Andrews, Of the Extra-Illustration of Books

John Mansir Wing, one of Chicago's great library benefactors, was an unrepentant Grangerite who for the last thirty years of his life pursued his two major hobbies: book collecting and extra-illustration. Born the son of a blacksmith in upstate New York in 1844, Wing spent his entire adult life around print, taking a job as a printer's devil when he was sixteen, and later working as a typesetter, printer and reporter for various newspapers in New York State. In June 1865 he moved to Chicago, where he worked as a freelance reporter for both the Chicago Tribune and the Times. In 1869, Wing began publishing The Land Owner, a real estate magazine. Although publication of The Land Owner ceased in 1877, Wing was already working on another magazine, The Western Brewer, concerning the grain market and brewery production. It should be noted that both of Wing's magazines, along with many of his other publishing endeavors, were essentially pastiche, consisting of "part news, part advertisements, and part puff."1 In 1888, one year after the establishment of the Newberry Library — an event Wing documented in one of his scrapbooks-he retired at the age of forty-four. Upon his death nearly 30 years later in March 1917, he left the bulk of his estate to the Newberry for the creation of the John M. Wing Foundation on the History of Printing. A discussion of a subset of Wing's book collection is taken up in his will, which reads: "That portion of my library comprising my Extra-Illustrated Books, which I have made with my own hands, and

1. Robert Williams, "John M. Wing," in Dictionary of Literary Biography, ed. Joseph Rosenblum (Greensboro, N.C.: The Gale Group, 1997), vol. 187, 348. 
upon which I have bestowed great expense, care and labor, I direct The Newberry Library to enclose in glass-front, dust-proof cases, place in the Memorial Room and keep constantly under lock and key, as this class of books are easily destroyed by handling." ${ }^{2}$

The term "extra-illustrated" is a general classification for books that have had material added to them by their owner, material that may be anything from a single portrait added as a frontispiece, to thousands of engravings, lithographs, photographs, maps, or letters. The term first appeared around 1878, and was used by book dealers to distinguish books with illustrations issued by the publisher from those that had been illustrated by the owner. ${ }^{3}$ The hobby, also called "grangerizing," dates back to 1769, the year in which the Reverend James Granger published A Biographical History of England from Egbert the Great to the Revolution, a collection of brief biographical sketches of those persons for whom engraved portraits were then available. Print collectors began tipping and inlaying portraits directly into their Grangers; illustrating his work "became quite a mania, and illustrated Grangers became thick as blackberries, and portraits became correspondingly scarce."4 Soon, people began adding illustrations not just to Granger's work, but to other books as well. Historical works were popular targets for extra-illustration, as were works by Shakespeare and Chatterton; but, as W.L. Andrews proclaimed, "Every book ever issued from the press is capable of some sort of extra-illustration."

The practice of extra-illustration created a great demand for prints and, unfortunately, came to be synonymous with biblioclasm, with the hobbyist viewed "as a sort of literary Attila or Gengis Khan, who has spread terror and ruin around him." ${ }^{\prime 6}$ The desire for portraits led some enterprising publishers to produce sets of facsimile prints, while book dealers were afforded the option of selling off unusable parts of their stock as "kits" consisting of portraits, views, and other prints suitable for the purposes of grangerization. ${ }^{7}$ Contrary to a long-standing Newberry myth that Wing cut up his own books, he essentially purchased prints by the pound. In an undated letter to a bookseller, he wrote, "I am engaged quite extensively in extra-illustration, and use several thousand prints a year. I will buy at a satisfactory

2. Papers of the John M. Wing Foundation on the History of Printing, Newberry Library.

3. H.J. Jackson, Marginalia: Readers Writing in Books (New Haven, Conn.: Yale University Press, 2001), 185.

4. Daniel M. Tredwell, A Monograph on Privately Illustrated Books: a Plea for Bibliomania (Brooklyn, N.Y.: F. Tredwell, 1881), 28.

5. W.L. Andrews, Of the Extra-Illustration of Books (London: Zaehnsdorf Cambridge Works, 1900), 13.

6. J.M. Bulloch, The Art of Extra-Illustration (London: Anthony Treherne \& Co., 1903), 12.

7. For a discussion of this subject, see: Lucy Peltz, "Facing the Text: The Amateur and Commercial Histories of Extra-Illustration, c. 1770-1840," in Owners, Annotators, and the Signs of Reading, ed. Robin Myers, Michael Harris, and Giles Mandelbrote (New Castle, Del.: Oak Knoll Press, 2005), 91-135. 
price a job lot of say 500 to 2000 portraits... to cover all countries except U.S." Moreover, in a preface to his extra-illustrated Lowndes' Bibliographer's Manual of English Literature, Wing declared, "I love books too well to destroy them. I prefer to have the vandal print-seller cut them up, and I buy the plunder, another but more conscience-soothing way of arriving at the same result." At the time of his death, Wing was rumored to have had in his possession over 7,000 loose prints; no books from his personal library show signs of mutilation.

Extra-illustration remained popular during the 1800 s, but by the end of the century the practice was fading. It was at this time that Wing picked up the hobby; he probably began extra-illustrating books sometime in the mid to late 1890s. At first, Wing created his books in his home, which he christened "The Old Corner Library"; but, after the death of his sister in 1911, he was given an office at the Newberry that he called his "cloister," where he pasted together his books and had many of them bound in the library's bindery. ${ }^{10} \mathrm{He}$ took his hobby so seriously that, in the 1910 U.S. census, he noted his profession as "Illustrator."

As a well-to-do retiree, Wing had both the time and money necessary for the hobby, which would have been a natural draw for him, since he loved elaborately illustrated books and despised newer methods of book illustration. In his family newsletter, The Owl, Wing discussed the art of books, stating: "Know ye all that the days when artists with needles toiled months over hard copper plates, engraving with wondrous skill the works of master printers in the golden age of art, are ended all. Nothing of the kind is now being produced-copper plate engraving is a lost art. Steel is going the same way, and wood engraving is about ended. It is now the cheap and nasty 'half-tone,' so called, because I suppose it has neither tone nor character at all, that is in vogue." ${ }^{11}$ He summed up his ardor for extra-illustration by stating, "I love to adorn my books with rare and curious plates... I love to do this work with my own hands, getting it all ready for the binder... There is a pleasure

8. John M. Wing to unidentified print dealer, n.d., Newberry Library.

9. Wing's copy [1901.4] of William Thomas Lowndes, The Bibliographer's Manual of English Literature, containing an account of rare, curious, and unusual books, published in or relating to Great Britain and Ireland, from the invention of printing (London: William Pickering, 1834). Since most of Wing's extra-illustrated books are not only uncatalogued, but also bear no resemblance to other copies, I have included standard bibliographical citations as well as references in brackets to entries in my bibliography of Wing's books in my unpublished master's thesis, A Bibliography of a Reader: the Extra-Illustrated Books of John M. Wing (University of Illinois, 2004).

10. Wing's copy [1913.1] of Edward Bulwer Lytton, The Caxtons: A Family Picture (Edinburgh: Wm. Blackwood \& Sons, 1849). In his colophon for this set, Wing wrote: "The work of extending these volumes was commenced at the Old Corner Library, June 1913, and completed at 'The Cloister' of The Newberry Library, October 1913. The deaths of the two sisters of the Illustrator made it imperative to break up the old home, where his favorite pastime of collecting and grangerizing had been carried on for nearly half a century. The books and prints were placed in The Newberry Library, September 1913, where it is his intention to create a Department of Bibliography."

11. John M. Wing, "A Great Wing Library," The Owl, 1.10 (June 1900). 
and sport in extra-illustrating books, rendering a volume unique, with not another like it in the world, which is fascinating and aristocratic." 12 These statements suggest that Wing, after a lifetime of writing anonymous newspaper articles and publishing journals on beer-making and real estate, wanted to make something more personal, which at the same time would aggrandize his life, and create his legacy, hopefully situating him on the bookshelf next to the authors and book artists he so admired.

While Wing's earliest extra-illustrated books are fairly typical of those produced by other hobbyists, by 1899 , the year that he first contacted the Newberry, he was evolving his own personal style of extra-illustration. Specifically, he began to date his work, and to insert comments, along with information about himself in the form of handwritten notes, printed captions, prefaces, colophons, and dedications. Most important, though, Wing included self-created title pages, which were not simply facsimiles of the original title pages (a common practice in extra-illustration), but instead tributes to himself and his grangerizing efforts. For example, on his title page for William Godwin's The Life of Geoffrey Chaucer (see figure 1), he calls himself:

A Pilgrim, with deft knife and paste,

In company of great renown;

With rare delight, quite to his taste,

Riding to Canterbury town-

Illuminating the Chaucerian Age

With apt engravings laid in every page. ${ }^{13}$

These self-supplied title pages — again, a form of pastiche—generally contain a decorated initial, cut out of a different book (perhaps an alphabet book) and often hand-colored by Wing; occasionally they even feature a title page border cut from elsewhere. The title pages come to be rather formulaic; they function as a means of drawing together fugitive illustrations and presenting them as a cohesive unit. They are generally divided into three sections: an uppermost section containing publication information about the original text that Wing illustrated; a middle section containing his "blurb" for the book he created, often announcing the number and types of prints he inserted; and a bottom section with the date the book was created and the name of the binder, as well as comments about Wing himself, some autobio-

12. Ibid.

13. Wing's copy [1909.1] of William Godwin, Life of Geoffrey Chaucer the early English poet, including memoirs of his near friend and kinsman, John of Gaunt, Duke of Lancaster: with sketches of the manners, opinions, arts and literature of England in the fourteenth century (London: printed by T. Davison for Richard Phillips, 1803). 


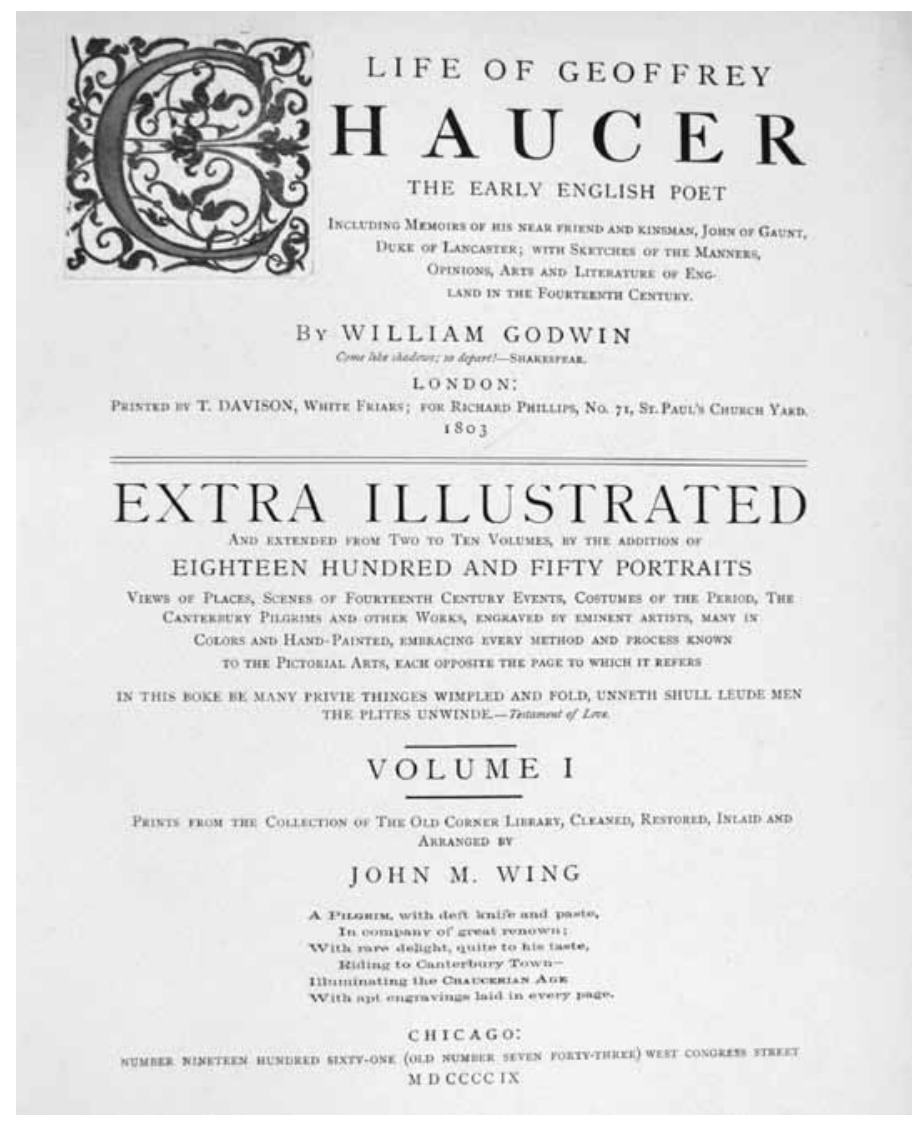

Figure 1. Wing's title-page for his copy of William Godwin's The Life of Geoffrey Chaucer, extra-illustrated in 1909. The Newberry Library.

graphical, and some probably fictitious. He almost always added a photo portrait of himself as a frontispiece, which, when coupled with his self-created title page, works to collapse the boundaries of author, illustrator, collector, and reader. Since Wing had established a relationship with the Newberry as early as 1899 and knew that his books would be placed there when he died, his title pages and frontispieces clearly reflect his intent of establishing a monument - through extra-illustrated apotheosis — on the bookshelves of the Newberry Library.

In total, Wing created over three hundred and fifty extra-illustrated volumes that encompass a variety of topics and genres. Much like his book collection, perhaps best described as "an eclectic 19th century gentleman's library," ${ }^{14}$ Wing's extra-illustrated books do not reveal a distinct pattern. Early on, he produced sets of commonly extra-illustrated texts, such as Granger's Biographical History, but he 
later became more imaginative, creating, for example, one volume on Robert G. Ingersoll's Letters on Suicide, probably not a popular choice for extra-illustration. Wing's collection also reveals a predilection for European literature and history, and some of his grandest, most urbane sets, including: The Comédie Humaine of Rabelais, The Age of Louis XIV, The Life of Geoffrey Chaucer, and Pageant of the Italian Renaissance reflect this interest. He also sporadically used magazine articles as his primary text, and twice even illustrated his own work, using Family Trees and Genealogy in 1903, and in 1905 The Anthology of Epitaphs, to which, amongst other illustrations, he added postcards, brochures and maps of Forest Home Cemetery, where he is now buried (see figure 2).

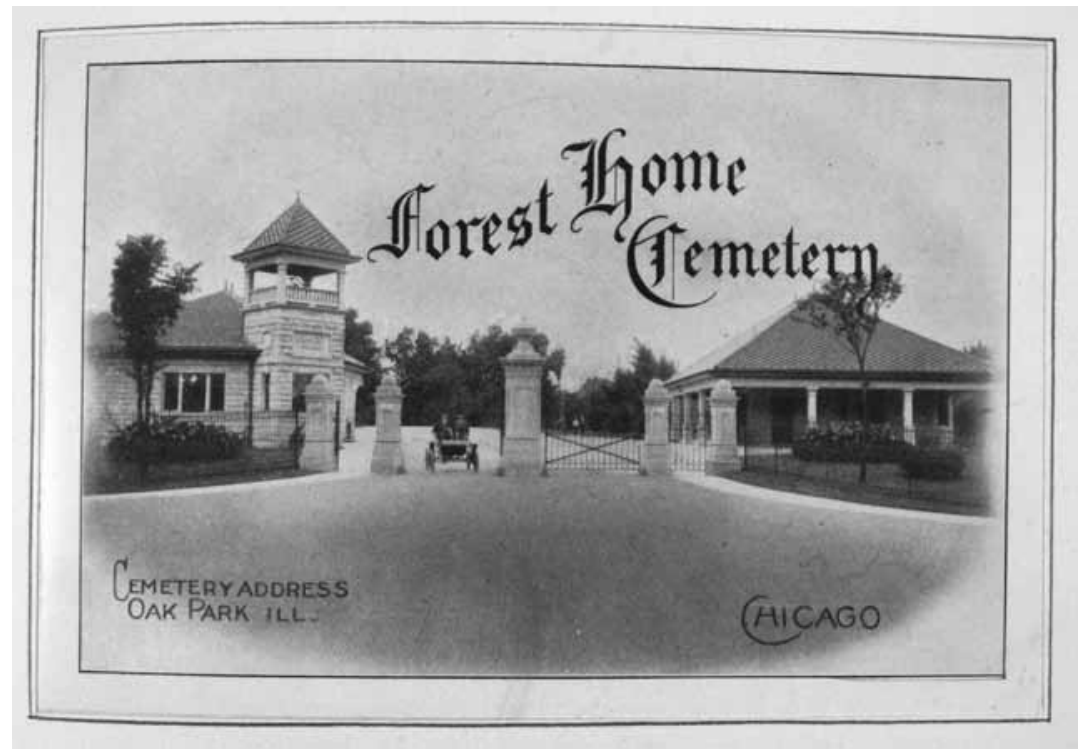

Figure 2. Postcard of Forest Home Cemetery, Oak Park, Illinois, used to extra-illustrate Wing's own text, The Anthology of Epitaphs, 1905. The Newberry Library.

In A Plea for Bibliomania, a classic text on extra-illustration, Daniel Tredwell asserted, "There are no general rules, no formulas, no beaten paths in this department of art-taste and genius are its only guides." ${ }^{15}$ Most extra-illustrators, however, tried to maintain some level of standardization in their work. Tredwell, along with many other grangerizers, disdained the idea of mixing types of prints, and the most diligent hobbyists would attempt to use only illustrations available when the book they were illustrating was first printed. ${ }^{16}$ Wing, though, claimed with pride that his books contained prints "embracing every method and process known to the decorative arts." ${ }^{17} \mathrm{He}$ declared, "The pleasure of 'Grangerizing' comes with license.

15. Tredwell, 16.

16. Ibid.

17. Wing made this statement on numerous title pages. 
I have fairly reveled in literary debauch, and for every print inserted I have my reason.... ${ }^{18}$ While Wing's books do contain substantial numbers of 17 th and 18th century engravings, he clearly had no compunction about mixing types of illustrative material. Along with thousands of portraits, views, and maps, the illustrative material comprises detached title pages, autograph letters, sheet music, newspaper clippings, menus, advertisements, and even junk mail, such as a 1910 Marshall Field's hosiery catalogue, included in its entirety (see figure 3). At present, an index of Wing's additions is being compiled, and work on all but 50 of the books has been completed, resulting in a database of nearly 30,000 entries.

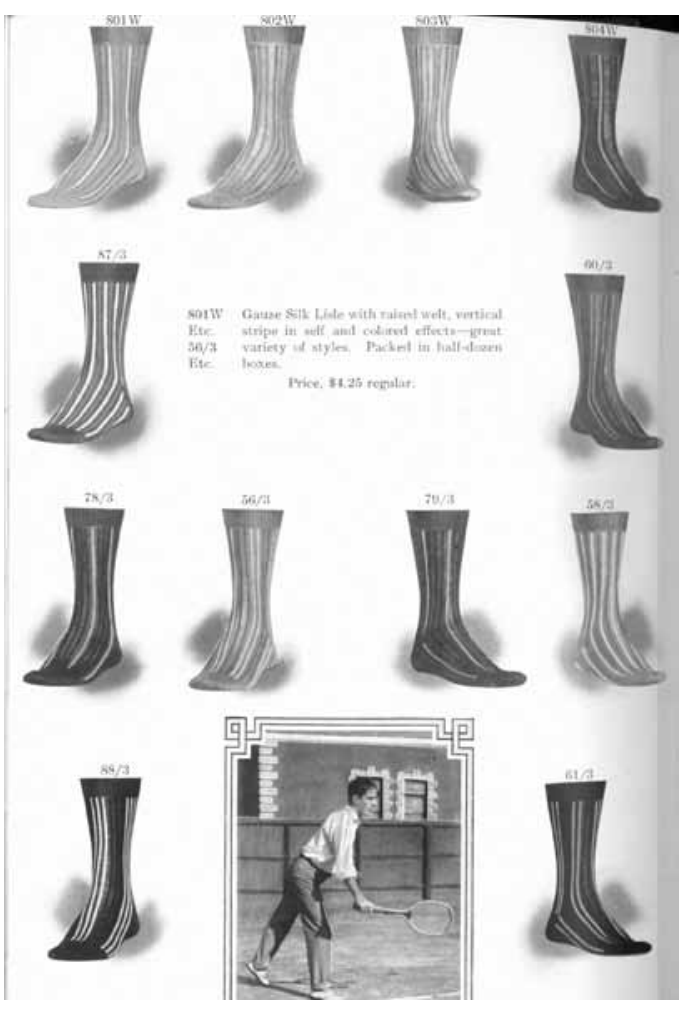

Figure 3. Marshall Field's hosiery catalogue. Added to Wing's copy of John Doran's Habits and Men and the Makers of Both, extra-illustrated in 1910. The Newberry Library.
Wing's most notorious addition even comes with its own story: in volume one of The Worship of Priapus, Wing included an "Illustrator's Preface," recounting in some detail his 1868 European tour with Charles Rogers, son of the founder of the Boston Daily Journal. The preface describes his first visit to Pompeii, stating:

I was bewildered by the Priapic symbols on every hand, carved on the tombs, on the door steps, along the frieze of the temples, painted in living colors on the roofless walls, standing erect over the marts of ancient commerce. I knew not its wonderful significance. I thought what a people this must have been to thus cover every avenue of their daily life with a figure regarded by modern civilization as obscene. Then I luckily picked up a bronze phallus, and preserved the relic as a souvenir. I have deposited it in a pocket in the last volume of this work, from whence I trust no vandal relic hunter will ever remove it, out of at least respect for a brother hunter, once a "Mighty Nimrod" in the chase of the curious. ${ }^{19}$

18. Wing's copy [1901.4] of The Bibliographer's Manual of English Literature.

19. Wing's copy [1904.4] of Richard Payne Knight, A Discourse on the Worship of Priapus and Its Connections with the Mystic Theology of the Ancients (London: privately printed, 1865). 
The phallus has indeed been removed, possibly by a vandal relic hunter, although in June, 1918 - one year after Wing's death-Newberry librarian William Carleton wrote in a memorandum, "It is further recommended that... all pictures, prints, and engravings of an objectionable, unedifying, or improper character be carefully removed from the Extra-Illustrated Books, and placed in sealed portfolios for consultation only by duly qualified members of the medical and other learned professions. Unless this or some similar measure is taken it will not be possible to utilize for any serious educational or research purpose the large amount of very valuable and useful material which these volumes contain." ${ }^{20}$ In addition to the phallus, there is a small amount of other material missing from various books, notably a section on maternity from The History of Women, and a dedication in the Dictionary of Painters and Engravers to Newberry librarian Alexander J. Rudolph, whom Wing called "the greatest librarian since Panizzi."

Bowdlerization notwithstanding, Wing's books are overflowing with prints: sometimes he added as many as sixty leaves of prints in between each page of text, thereby pushing the original text out to the margins and placing the once ephemeral illustrations in the authoritative spaces within each book. On his title pages, Wing always trumpets the included prints as "Rare and Exotic," a statement that again works to substantiate, and even exalt, his additions, no matter how mundane they might actually be. Now as someone who spent his entire working life in the printing industry, and who in retirement became a book collector, a keeper of scrapbooks, and a passionate extra-illustrator, Wing certainly knew the distinction between 17 th century engravings and 20th century hosiery catalogues, but he simply chose to ignore, or even mock, the conventions of extra-illustration. I would go so far as to suggest that, throughout his life, Wing essentially saw all printed material as recyclable, if not ephemeral, for not only did he preserve fugitive items, but he also detached and recontextualized items that had a certain permanence as issued. In fact, he even (half-jokingly of course) acknowledged the ephemerality of his own grangerizing efforts: on his title page for Dibdin's Bibliomania he writes of hundreds of extra-illustrated books "hidden away in the book-vaults of the Old Corner Library, awaiting in turn destruction by future generations of book-vultures, thirsting for old prints, who will gnaw the odiferous paste like rats, gorging their madness on his folly."22 Given that Wing laid out such specific instructions for

20. Papers of the John M. Wing Foundation on the History of Printing, Newberry Library.

21. Wing's copy [1902.4] of Shearjashub Spooner, A Biographical and Critical Dictionary of Painters, Engraves, Sculptors and Architects, from Ancient to Modern Times (New York: George P. Putnam \& Co., 1853). Although the dedication has been removed from the extra-illustrated set, Wing included a copy of it in one of his personal scrapbooks. The comparison to Panizzi relates to Rudolph's invention of a hand-rotated card catalogue, called the Rudolph indexer.

22. Wing's copy [1904.2] of Thomas Frognall Dibdin, Bibliomania or Book-Madness ([New York]: privately reprinted for the Club of Odd Sticks, 1864). 
the care of his books after his death, it is clear that he intended his body of work to be kept pristine; yet he was still able to at least imagine his books as being reused by others.

From his writings in his extra-illustrated books, it is apparent that Wing was obsessed with both decay and monument, perhaps not so unusual for someone who had lived through both the Civil War and most of World War I and experienced firsthand the ravages of war as well as the memorials that sprung up in their wake. He repeatedly promulgated the degeneration of society, specifically the printing industry, suggesting not only that magazines were being written by "love-cracked maids and androgynous persons in trousers," ${ }^{23}$ but also that "Great books are of the past. One can only be made now with Paste Pot and Inlaying Knife, patiently restoring the treasures of happier days." ${ }^{24} \mathrm{He}$ was obsessed as well with the ruins of Europe, as evidenced by his stories of Pompeii. He was also quite cognizant of the deterioration of his own body, claiming that he was but "an old book-man [who] waits in earthly pain / To be 'inlaid' from whence he came." ${ }^{25}$ Here Wing is making a bad, if not terrible, pun, but his statement fits perfectly with what he was trying to achieve via his extra-illustrated books. He seemed to recognize the simultaneous fragility and permanence of books and other printed material. $\mathrm{He}$ conflated bibliographical fragility with physiological deterioration, but he also realized that through his extra-illustrated books he could create permanence out of the ephemeral. Wing's books were the perfect building blocks for his imagined bibliographical monument, for they are built on the shoulders, so to speak, of great authors like Voltaire, Chaucer, and Rabelais. To read through the books is to be let into Wing's life for a brief while: to view his collection of prints, to see pictures of him, to read his junk mail, and ultimately to do what Wing intended-remember him as a printer, an illustrator, a book collector, and a benefactor of the Newberry Library.

23. Wing's copy [1905.4] of Peter Cunningham, The Story of Nell Gwyn, and the Sayings of Charles the Second (New York: John Wiley's Sons, 1891).

24. Wing's copy [1907.2] of F. Espinasse, “The House of Murray,” Harper's Magazine, September 1885: 503-22.

25. Wing's copy [1901.4] of The Bibliographer's Manual of English Literature. 